\title{
Article
}

\section{Is China's Belt and Road Initiative Moving towards a Silk Road Union?: A Legal and Policy Consideration}

Ran Guo*

In order to facilitate its Belt and Road Initiative, China has issued dozens of policy documents and detailed guidelines, improved its legal and supervisory systems, and taken full advantage of all existing cooperation mechanisms at the bilateral, regional, sub-regional and multilateral levels. The current cooperation mechanism is characterized by non-systemicity, which makes it dependent upon other existing regional cooperation mechanisms. In fact, it has no uniform institutional structure, nor any dispute settlement mechanism. Although this non-systematic approach is based in China's successful experience in opening up to outside influence and in the flexibility that enabled its rise to global prominence, this very flexibility also poses challenges to the implementation of the Belt and Road Initiative by leaving it open to conflict with existing regional cooperation mechanisms. Therefore, to ensure the success of the Belt and Road Initiative, China should undertake a systematic plan for implementation by establishing a comprehensive legal framework; streamlining paths to economic cooperation; and institutionalizing the cooperation mechanism with a formal dispute settlement mechanism at its core.

Keywords: Silk Road Union, Belt and Road Initiative, Cooperation Mechanism, Institutionalization, Dispute Settlement Mechanism

* Professor of International Law at Shanghai Maritime University, China. B.A. (Henan Normal Univ.), M.A. (Tianjin Foreign Studies Univ.), Ph.D. (Wuhan). ORCID: https://orcid.org/0000-00018450-6495. He was a Visiting Fellow $(2016-2017,2018)$ at Lauterpacht Centre for International Law and Wolfson College, University of Cambridge, UK, and a Fulbright Visiting Scholar (20072008) at Hampden-Sydney College, USA. This research was supported by "The Protection of Underwater Cultural Heritage China's Maritime Silk Road" (2018BFX001) sponsored by the Shanghai Planning Office of Philosophy and Social Science. The viewpoints expressed in the article are the author's own and do not represent those of any institution or that of the Chinese government. The author may be contacted at: ranguo2008@aliyun.com/Address: School of Law, Shanghai Maritime University, 1550 Haigang Ave., Pudong District, Shanghai, P. R. China 201306. All the websites cited in this article were last visited on February 6, 2020. 


\section{INTRODUCTION}

The Initiatives of Jointly Building the Silk Road Economic Belt and the 21st-Century Maritime Silk Road (hereinafter the Belt and Road Initiative; "BRI") were proposed by Chinese President Xi Jinping in 2013. In March 2015, China issued The Vision and Actions on Jointly Building Silk Road Economic Belt and 21st-Century Maritime Silk Road (hereinafter The Vision and Actions), which enunciated the guiding principles, framework, priorities and mechanisms of the BRI. ${ }^{1}$ To implement this Initiative, China focuses on five priorities, including policy coordination, facilities connectivity, free trade, financial integration and people-to-people communication, with an ultimate purpose of building "a community of shared interests, destiny and responsibility featuring mutual political trust, economic integration and cultural inclusiveness."

The BRI codifies China's contributions to global governance based on the principle of mutual benefit and win-win cooperation. It also represents China's commitment to creating an intimate community of shared destiny with the Asian Infrastructure Investment Bank ("AIIB"), the Silk Road Fund and various infrastructure construction projects. In pursuing the BRI, however, China has not formulated any new systematic cooperation mechanism. Instead, it intends to take full advantage of the existing cooperation mechanisms, forums and platforms to push forward the BRI. ${ }^{4}$

This non-systematic cooperation mechanism has divided the opinions of international lawyers. Some have argued that China should employ a non-systematic approach at this early stage without establishing any institutions like a Council, Commission or Secretariat of the BRI. ${ }^{5}$ Meanwhile, many international lawyers insist that the BRI cannot be legitimately implemented without concluding multilateral agreements and establishing an international organization with a unified institution. ${ }^{6}$ Some have proposed building an energy community along the Silk Road, ${ }^{7}$ while others have gone even further by proposing to create a Silk Road Union - a transcontinental association of the Belt and Road ("BR") countries. ${ }^{8}$

This research will comprehensively examine the current legal and policy documents on the cooperation mechanism under the BRI, exploring its legal basis, characteristics and defects from the perspective of international law, with a view to proposing constructive suggestion for its improvement. This article is composed of five sections including Introduction and Conclusion. Part two will conduct a thorough investigation of China's laws and policies on the implementation of the BRI, seeking 
to identify whether there is a unified legal and policy basis for a possible Silk Road Union. Part three will analyze the current cooperation mechanism under the BRI and the challenges it faces to uncover whether it is capable of meeting these challenges. Part four will make tentative proposals for improving the cooperation mechanism as a potential alternative to a Silk Road Union.

\section{China's Belt and Road Initiative: A Unified Constitutional Framework?}

The development of the BRI is an empirical progressive process: first, China established an oversight body or "leading group" and put forward its general vision and actions; then it worked to enrich the content of those vision and action statements and refined the proposed implementation measures; finally, it created problemsolving plans to address specific issues and promote international cooperation in an incremental process.

\section{A. China's Policy Documents on the BRI}

In order to implement the Vision and Actions, various Chinese ministries and commissions have formulated a range of plans to detail the actions to be taken under their respective responsibilities, and to simultaneously promote domestic and international cooperation. (1) With respect to 'connectivity,' China issued The Action Plan on BR Standard Connectivity (2015-17) and an updated 2018-20 version ${ }^{10}$ so as to provide solid technical support that can promote the interconnection and construction of infrastructure; improve international cooperation regarding capacity and equipment manufacturing; and facilitate investment and trade. (2) With respect to cultural and people-to-people exchanges, China issued its Action Plan for BR Cultural Development (2016-20) to deepen the mutual understanding between different BR countries and regions and to effectively promote cultural communication and cultural trade. ${ }^{11}$ (3) In terms of investment and financing, China ratified the Articles of Agreement of the Asian Infrastructure Investment Bank in November 2015, according to which the AIIB started operation on December 25, 2015, thereby scaling up financing support for the infrastructure required by the BRI. ${ }^{12}$ The Guiding Principles on Financing the Development of the BR was adopted at the BR Forum for 
International Cooperation in May 2017 in order to foster tangible progress towards financial integration among the BR countries. ${ }^{13}$ (4) With respect to environmental protection, China released The BR Ecological and Environmental Cooperation Plan in May $2017^{14}$ and the Guidance on Promoting Green BR in June $2017^{15}$ to promote green development, strengthen environmental protections and jointly build a green Silk Road with partner nations. (5) In order to build a peaceful and prosperous 21st-century maritime Silk Road, China issued The Vision for Maritime Cooperation under the BRI in June 2017 which is China's first blueprint for its "blue economy" prioritizing the cooperation in areas marine environmental protection, connectivity of maritime infrastructure and facilities, and collaborative ocean governance. ${ }^{16}$

Given these top-level policies as well as those forthcoming, all relevant ministries and committees of the Chinese government have created implementation plans for the Vision and Actions to support the BRI.

\section{B. China's Legal and Administrative Measures on the BRI}

In order to resolve any legal disputes arising in relation to the BRI, the Supreme People's Court ("SPC") of China has promulgated judicial opinions ${ }^{17}$ and model cases ${ }^{18}$ that have played a guiding function for trial and enforcement by Chinese courts at various levels, especially on some key legal issues with respect to the choice and proof of foreign law, application of international conventions and reservation of public order, etc. ${ }^{19}$ More importantly, China has set up new judicial institutions to create a one-stop dispute resolution centre for parties from the BR's participating countries. ${ }^{20}$ On June 25, 2018, the SPC issued Regulations on Several Issues regarding the Establishment of International Commercial Courts, which sets out the scope and operation of two new international commercial courts in China: (1) Xi' an International Commercial Court, focusing on disputes arising from projects along the Silk Road Economic Belt, and (2) Shenzhen International Commercial Court, focusing on disputes arising from infrastructure developments along the 21st Century Maritime Silk Road. ${ }^{21}$ On August 26,2018 , the SPC established a 32-member committee of international commercial experts to advise on ways to resolve international commercial disputes and offer suggestions on dispute-related legal issues, as well as on development of the rules, programs, judicial interpretations and policies to be elaborated. ${ }^{22}$ Thus, China has established an international commercial dispute settlement mechanism and institutions, which have integrated mediation, arbitration and litigation into a single platform to 
provide judicial services and protections for the purpose of implementing the BRI.

According to the top-level design proposed for Chinese enterprise's overseas investment, the ministries and committees of the Central Government of China have launched various measures to improve their administrative and service systems ${ }^{23}$ with an ultimate purpose to better administrate, supervise and support Chinese enterprises, both state-owned and private enterprises, seeking international cooperation. ${ }^{24}$

\section{International Cooperation Agreements on the BRI}

In order to promote the effective integration of the BRI with the national strategies, development visions and overall plans of the BR countries, China has negotiated and concluded a number of bilateral and multilateral cooperation agreements with these countries. By the end of March 2019, China had signed 173 cooperation agreements with 154 countries and international organizations. ${ }^{25}$

According to the Guidelines on Construction of China-Mongolia-Russia Economic Corridor, ${ }^{26}$ China, Mongolia and Russia will cooperate to build a trilateral economic corridor. The Cooperation Plan on Dovetailing the Silk Road Economic Belt and Nurly Zhol (Bright Road), signed between China and Kazakhstan, enshrines the nations' joint commitment to in-depth integration and mutual promotion, which has become a model for the BR countries that wish to participate in the BRI. ${ }^{27}$ The Agreement on Economic and Trade Cooperation between the Eurasian Economic Union ("EAEU") and China ${ }^{28}$ marks the first important institutional arrangement on the economic and trade relations between the EAEU and China. As a key feature of the agreement, the parties agree to further simplify customs clearance procedures and reduce the cost of trade in goods by strengthening their cooperation and information exchange efforts. This marks a new stage in the economic and trade cooperation between China and the EAEU and its member states.

These bilateral and multilateral agreements cover a broad range of areas such as connectivity, production capacity, investment, economy and trade, finance, science and technology, humanities and marine issues. In their efforts to support the BRI, a range of Chinese government ministries and commissions have released various policy documents and implementation plans to detail what actions they plan to undertake given their respective responsibilities. ${ }^{29}$ Notably, China has made concerted efforts to improve its domestic legal and administrative system in order to facilitate international cooperation, particularly between Chinese and foreign enterprises. Moreover, China 
has concluded a number of international agreements and arrangements to set up structured cooperation mechanisms to support the BRI. These policy documents, relevant legal and regulatory documents, and international cooperation agreements have formed a preliminary basis for cooperation mechanism of the BRI.

\section{Characteristics and Challenges of THE BRI COOPERATION MECHANISM}

The relevant laws and policy documents described in Part II illustrate the cooperation mechanism woven into the fabric of the BRI. On the whole, the cooperation initiative demonstrates three key characteristics - openness and inclusiveness, complex laws and policies, and non-systemicity - each with a number of sub-facets that pose a series of opportunities and challenges to the successful implementation of the BRI.

\section{A. Openness and Inclusiveness}

\section{Promoting Openness}

One of the guiding principles behind the BRI is its commitment to promoting openness between participating nations. The openness of the cooperation mechanism is reflected by the variety of participant countries, wide area of involved regions and mixture of bilateral and multilateral mechanisms used to structure the initiative. From its inception, the BRI was envisioned as an inclusive effort. Indeed, the BRI "covers, but is not limited to, the area of the ancient Silk Road"; all countries, international and regional organizations, NGOs and enterprises can participate. ${ }^{30}$ China not only attaches great importance to the existing bilateral mechanisms, but also encourages the signing of new cooperation memoranda of understanding ("MOUs") or plans and the establishment of bilateral joint working mechanisms. To further the BRI's aims, China also makes full use of existing multilateral cooperation mechanisms and international platforms, such as the Shanghai Cooperation Organization ("SCO"), Asia-Pacific Economic Cooperation ("APEC"), Bo'ao Forum for Asia, and so on. ${ }^{31}$ For example, in order to promote agricultural cooperation, China not only facilitates bilateral cooperation between governments, but also gives full support to existing agriculture-related multilateral mechanisms, such as the G20, APEC, SCO, the United Nations Economic and Social Commission for Asia and the Pacific ("UNESCAP"), 
the Asia Cooperation Dialogue, the League of Arab States, China-ASEAN and the Lancang-Mekong Cooperation. China also participates in major conferences and forums actively, such as the China-Africa Cooperation Forum, Roundtable Meeting on ASEAN Plus Three Food Security Cooperation Strategy, the China-ASEAN Exposition, the China-Eurasia Exposition, the China-Central and Eastern European Countries Economic and Trade Forum and the China-Arab States Exposition. ${ }^{32}$ In addition, China is committed to working with relevant countries to establish a dialogue mechanism for agricultural cooperation, a research and communication platform for agricultural planning and an information-sharing platform for agricultural resources. ${ }^{33}$

\section{Enhancing All-around Economic and Cultural Cooperation}

The cooperation mechanism of the BRI is not limited to facilitating open exchanges of goods and services. Rather, it deals with comprehensive economic and cultural cooperation among all BR countries. It facilitates holistic, pragmatic cooperation with respect to policy coordination, systems connectivity, and unimpeded trade, investment and cultural exchange, so that all countries can realize economic and cultural development and prosperity. ${ }^{34}$

Developing modern, reliable infrastructure is the key to economic improvement and integration of nations and transnational blocs. China works with the BR countries to build railways, highways, ports, information and telecommunications facilities to enhance the transnational connectivity of infrastructure and facilities. For example, China and the European Commission have engaged in cooperation on the EU-China Connectivity Platform since 2015. The China-Europe Railway Express has begun operating, connecting 42 cities in 14 European countries and providing myriad social and economic benefits to locals. ${ }^{35}$ China has signed 16 bilateral or multilateral agreements regarding the facilitation of transport, including the Intergovernmental Agreement of the SCO Member States on the Facilitation of International Road Transport and the Intergovernmental Agreement on International Road Transport along the Asian Highway Network. ${ }^{36}$ In the Asian sphere, China, Laos, Myanmar and Thailand have compiled the Development Plan of International Navigation on the Lancang-Mekong River (2015-25) to promote the cooperative development of navigation facilities on this key waterway. China is also cooperating with relevant countries to promote improvements in the energy sector such as building oil, gas and power infrastructures and ensuring the safe operation of cross-border oil and gas 
pipelines. The China-Russia Oil Pipeline and China-Central Asia Gas Pipelines are all operating reliably. Building on this success, construction has started on the ChinaCentral Asia Gas Pipeline D, the eastern route of the China-Russia Gas Pipeline, and priority energy projects are listed in the China-Pakistan Economic Corridor Cooperation Plan. ${ }^{37}$ As of March 2019, China had signed bilateral air transport agreements with 126 countries and regions. ${ }^{38}$

In terms of economic and trade cooperation, China has actively negotiated with the BR countries to build a free trade zone network. As part of China's global outreach, the China-ASEAN Free Trade Area ("FTA") has been upgraded, and China has completed FTA negotiations with Georgia. Real progress has been achieved in talks on the Regional Comprehensive Economic Partnership ("RCEP"), the China-Maldives FTA, the China-Gulf Cooperation Council FTA, the China-Israel FTA, the China-Sri Lanka FTA and the China-Pakistan FTA, bringing the goal of a concerted breakdown of barriers to open trade closer to fruition.

China is also committed to international cooperation to expand production capacity and mutual investment. It has encouraged domestic enterprises to "Go Global!," urging them to cooperate with the BR countries to increase production capacity, bolster equipment manufacturing and engage in mutual investment. By the end of March 2019, China had concluded 40 production capacity cooperation documents with Kazakhstan, Ethiopia, Brazil and other countries. ${ }^{39}$

In order to create a stable financial environment for the BRI, China is working to create a network of flexible financial institutions and platforms, including the Chinaproposed AIIB and the Silk Road Fund. It hopes that such institutions will support the BRI through innovative financing mechanisms. China has signed currency swap agreements with 22 BR countries; executed local currency settlement agreements with Vietnam, Mongolia, Laos and Kyrgyzstan; and concluded agreements on general trade and local currency settlement in investment with Russia, Kazakhstan, Belarus and Nepal. The Cross-Border Interbank Payment System provides Renminbi (RMB) services to domestic and foreign financial institutions, easing transactional issues that might otherwise stall investment and development initiatives. ${ }^{40}$

Traditionally, economic and infrastructure expansions are associated with negative environmental impacts. In pursuing the BRI, China is attempting to prove that this negative relationship is not necessary. In order to build a 'green' Silk Road, China has committed to sharing its newest technology and best practices in the areas of 
ecological restoration and environmental protection. To this end, China has built a cooperation platform highlighting environmental issues, hosted the China-Arab Forum on Environmental Cooperation and the Forum on China-ASEAN Environmental Cooperation; and founded the China-ASEAN Environmental Cooperation Centre. ${ }^{41}$

In a globalized world, overland routes are not the only key pathways to transnational movement of goods, services, ideas and people. With respect to maritime matters, China is striving to upgrade or build key ports in cooperation with their host countries, helping these nations develop both port-centred industries and their hinterland economy; maintain safe sea passages; and cooperate on issues affecting maritime trade, the economy and connectivity. ${ }^{42}$ For example, Chinese enterprises have undertaken a number of initiatives including the construction of Pakistan's Gwadar Port, Sri Lanka's Port of Hambantota, the China-Malaysia Malacca Seafront Industrial Park and the comprehensive development of Kyaukpyu Port in Myanmar. ${ }^{43}$

\section{Addressing Conflict between Cooperation Mechanisms}

Despite the ambitious goal of connecting all nations and breaking down barriers to global cooperation, the openness and all-inclusive nature of the BRI will inevitably lead to conflicts with existing multilateral and regional cooperation mechanisms. In Central Asia, it may overlap and even conflict with the EAEU and the Collective Security Treaty Organization ("CSTO"), which in combination constitute a single de facto structure. ${ }^{44}$ Although the CSTO (which currently has six member states: Armenia, Belarus, Kazakhstan, Kyrgyzstan, Russia and Tajikistan) aims to create a collective security system, "it is evident that the only effective method of consolidating the CSTO is to unite the national economies of Eurasian countries into an effective economic alliance." ${ }^{45}$

Meanwhile, the EAEU (which currently includes five member states: Armenia, Belarus, Kazakhstan, Kyrgyzstan and Russia) acts essentially as an economic integration organization, pursuing a possible Eurasian customs union and a single economic space. Beyond these organizations, Japan launched the "Central Asia Plus Japan" dialogue mechanism in 2004 to revive Japan's version of Silk Road diplomacy, first introduced in 1997 by then Prime Minister Hashimoto Ryutaro, in order to ensure the continuity of its Central Asian energy supply. ${ }^{46}$ In Southern Asia, India has strengthened its role in the Indo-Pacific region, which may indicate the revival of the so-called quadrilateral strategic alliance between the US, Japan, Australia and India in 
an attempt to counter China's rise. ${ }^{47}$ The Indo-Pacific energy strategy may challenge China's attempts to better connect energy facilities and construct an energy corridor as part of BR. ${ }^{48}$

China has been working to resolve these conflicts in cooperation with relevant countries. As early as May 2015, China and Russia signed a joint statement regarding their desire to dovetail various Silk Road Economic Belt projects with those promoted by the EAEU, in order to increase synergy between the two initiatives in the region, thereby promoting the goals of both. ${ }^{49}$ In July 2017, China and Russia released the Joint Declaration of Further Deepening the Comprehensive Strategic Partnership of Coordination in Moscow, a first attempt at integrating the aims of the BRI and the EAEU. ${ }^{50}$ On June 8, 2018, China and Russia signed the Joint Declaration of the Joint Feasible Studies on Completing Eurasian Economic Partnership Agreement in Beijing. It recommends that both parties launch negotiations on service trade, investment, natural person mobility, e-commerce, intellectual property rights, competition, energy saving and efficiency enhancement efforts, economic and technological cooperation, SMEs, government procurement, institutional arrangements and trade in goods. ${ }^{51}$ However, much has yet to be done before the two parties are able to fulfil necessary domestic procedures, conduct negotiations and finally establish a comprehensive, highlevel investment arrangement that will be open to other economies in the Eurasian region.

It also remains to be seen how China will resolve possible conflicts with other regional integration programs. In Southeast Asia, due to various disputes over territorial sovereignty and maritime interests in the South China Sea ("SCS"), states including Vietnam and the Philippines are reluctant to pursue all-around economic and cultural cooperation between China and ASEAN; these nations may even attempt to undermine cooperative efforts. ${ }^{52}$ Meanwhile, "states out of the region have increased their military activities, joint maritime exercises and military operation in the SCS to strengthen their military presence and influence in Southeast Asia." ${ }^{, 53}$ In particular, the US has been working to build a strategic partnership with the ASEAN states to strengthen its influence and protect its so-called "national interests" in the region, ${ }^{54}$ which may have a negative influence on the 21st Century Maritime Silk Road. In July 2013, the US resumed its New Silk Road Strategy, which aims to promote the American economic engagement in Central Asia, and particularly Afghanistan. ${ }^{55}$ Meanwhile, Japan has taken over the leadership of the Comprehensive and Progressive 
Trans-Pacific Partnership Agreement after the US withdrew from the effort in an attempt to reduce Chinese economic influence in the region and shift economic balances and alliances within Asia. ${ }^{56}$ Both of these efforts will impede the success of the BRI if some sort of cooperative arrangement cannot be reached to reduce the unproductive tensions at play.

\section{B. Complex Laws and Policies}

\section{Diversity of the Legal Sources of the BR Cooperation Mechanism}

The policy documents of the Chinese government demonstrate that the legal and policy basis of the BR cooperation mechanism is complex. It draws on diverse policy documents and implementation plans issued by relevant Chinese government ministries and committees; bilateral multilateral cooperation agreements and joint statements signed between China and participating countries and international organizations; and various position papers issued by international organizations and platforms. Moreover, MOUs, declarations and communiqués released by various international organizations and platforms are also indispensable components of the principles comprising the $\mathrm{BR}$ cooperation mechanism. ${ }^{57}$

China's BRI is an attempt to forge more cohesive international bonds among the nations of the world. It is thus "in line with the purposes and principles of the UN Charter. It upholds the Five Principles of Peaceful Coexistence: mutual respect for each other's sovereignty and territorial integrity, mutual non-aggression, mutual noninterference in each other's internal affairs, equality and mutual benefit and peaceful coexistence. ${ }^{, 58}$ These are the basic principles of both the BRI and international law governing bilateral and multilateral cooperation agreements. At the core, these efforts are aligned. In accordance with these principles, China has created domestic policy documents and action plans to support the BRI.

Next, China undertook efforts to engage in talks with the BR countries regarding China's ideas, attempting to reach a broad consensus supporting cooperation. These efforts yielded a number of declaratory documents on the BRI. ${ }^{59}$ As more countries and international organizations are acknowledging and supporting the BRI, China began working with relevant countries to conclude MOUs, mid-term and long-term economic cooperation plans and cooperation agreements to integrate the BRI with individual nations' development plans. As a result, China and its partner countries are able to facilitate the development of implementation policies in various fields 
and support domestic and international enterprises which carry out a range of BR projects. In short, from the perspective of international law, the legal sources of the BR cooperation mechanisms include general legal principles, multilateral and bilateral agreements, and relevant international conventions, forming a multi-layered but fragmented legal source system. ${ }^{60}$

This is reflected in the wide variety of applicable laws recognized by the SPC of China. The People's Courts at various levels are obliged to correctly apply international law, both treaty and custom, as well as to identify and apply foreign law. ${ }^{61}$ Given this explicit intent to adhere to international treaty, custom and legal procedure, the BR cooperation mechanism consists of an open economic and cultural exchange based on various domestic policy documents and bilateral and multilateral agreements, which are implemented through a range of formal and informal organizations and platforms. ${ }^{62}$

\section{Lack of Effective Dispute Settlement Mechanism}

Although the BRI is predicated on a respect for the rule of law internationally and founded on principles of bilateral and multilateral cooperation, challenges to the implementation and promulgation of the initiative would remain. Guluzian noted: "This ambitious multinational project comes with serious obstacles: unstable political regimes within host countries [and] subpar international business practice standards, including non-transparency and corruption." ${ }^{63}$ Some participating countries are not World Trade Organization ("WTO") members, such as Turkmenistan, Uzbekistan, Afghanistan, Azerbaijan, Bahrain, Iran, Iraq, Lebanon and Syria. For them, barriers to international trade and investment persist, while laws on market access and infrastructure construction vary considerably. When there is no coordination mechanism between the ports of two countries, repeated customs clearance, inspection, quarantine and taxation issues will inevitably lead to slow customs clearance, trade delay and increased costs. ${ }^{64}$ These issues are at the heart of China's desire to improve standards and coordination between nations, removing barriers to productive trade indeed at the heart of the BRI itself. At present, the cooperation priorities of the BRI are mainly related to infrastructure construction and energy projects, which are characterized by enormous investments, extremely long-term contracts, and the presence of a dominant party, typically either the government or a state-owned enterprise of the host country. The dominant party acts as one party to the contract and at the same time controls the 
framework and implementation of the project. ${ }^{65}$ As there is no unified convention or economic custom in these areas of international cooperation, political goodwill must play a decisive role in any successful coordination, and particularly in the settlement

of any dispute. ${ }^{66}$ For these challenges, the Chinese government and enterprises have faced higher uncertainty and complexity, seeking cooperation and engagement with host countries.

Moreover, territorial disputes, geopolitical entanglements, military alliances and conflicts abound between different countries. Major countries including the US, Russia, India and Iran have historically exerted military, geopolitical and economic influence over the BR countries and continue to do so today. Their strategic competition in the region has exacerbated territorial disputes, further increasing the uncertainty and risk faced in implementing the BR cooperation mechanism. ${ }^{67}$

\section{Non-systemicity}

The BRI is a systematic project, which is designed to be jointly built through consultation to meet the interests of all, thereby integrating the development strategies of the BR countries. ${ }^{68}$ In practice, however, it is not systematic at all. Its "institutional structure is not fixed once and for all, but rather flexible"; it has "no intention to set up its own institutions, but promotes an adequate play of various existing international, regional and sub-regional, bilateral organizations and forums. ${ }^{.69}$ Indeed, even its membership is not fixed, but open to all countries and organizations in the world, including those countries along the BR corridor. Further, it neither has a decisionmaking body, nor intends to enact its own rules and procedures. The BR cooperation mechanism is merely adaptive and flexible that can adjust to suit the needs of different participants and different fields of cooperation. ${ }^{70}$

This non-systemic, non-institutionalized cooperation mechanism is one of the most negative features of the BRI, which has been labeled by some international lawyers as "an abstract or visionary project." " Despite its lofty aims, its disadvantages are obvious. First, such an initiative cannot be independent from existing regional cooperation mechanisms. For instance, since the SCO is a political, economic and security framework, the overlap of its membership and functions with the BRI will place political, diplomatic and even security pressure on economic and cultural cooperation between interested nations, potentially to the detriment of trade and economic agreements, particularly in the case of dispute settlement. ${ }^{72}$ Second, the 
BRI's nascent structure is still rather fluid, given the lack of intent to institutionalize or create its own decision-making rules and procedures. ${ }^{73}$ However, the exchange structures that have been created thus far, such as the BR international summits, forums, conferences and exhibitions, are not enough legalized and institutionalized to solve major regional or global issues by cooperation. ${ }^{74}$ Third, the BRI does not have its own dispute-settlement mechanism. Instead, it can only resort to existing dispute settlement mechanisms supported by various international organization and platforms, such as the WTO, as well as the arbitration procedures implemented by interested institutions.

Such non-institutionalized, non-systematic framework finds its roots in China's path to successful economic development during its opening-up period. China has made remarkable achievements by adhering the philosophy that "One can wade across the stream by feeling the way [摸著石頭過河].” By learning from its successful experience, therefore, China has resorted to the same philosophy and adopted a flexible and non-institutionalized framework for its new major initiative: the BRI. At present, the BRI is in its infancy. China started from the ground up during its opening-up. Thus, China is drawing upon its previous successes to design a roadmap for the BRI, neither establishing any new institutions, nor concluding any uniform international conventions regarding the initiative.

Instead, it will seek progress through experiential learning and adaptation, using the "experiment-feedback-revision-experiment" model within the framework of existing norms and institutions. ${ }^{75}$ However, this path is inconsistent with the traditional institutionalization on which all existing cooperation mechanisms with respect to international trade, environmental protection, human rights and the use of force are established. Systematic advance planning is the essence of this tradition. Its methodology relies on conducting thought experiments ${ }^{76}$ to consider some potential institutional structure and its hypothetical consequences. An institutional framework is then devised on the basis of certain norms and organizational needs and further steps are later taken to establish or improve its statutes and procedural rules. ${ }^{77}$ In other words, a traditional cooperation mechanism normally comprises certain institutions endowed with the powers and functions necessary to facilitate the implementation of its aims, such as a plenary organ, executive group of technocrats, or dispute settlement agency. ${ }^{78}$ Such a systematic planning approach is the first choice of the global community for establishing international cooperation mechanisms. It conforms to the 
implied requirements for certainty, clarity and predictability necessary to a cooperation mechanism.

As regard the current BR cooperation mechanism, the biggest drawback is the responsibility for constructing the BR itself placed within the scope of the political will of participating countries. Theoretically, economic prosperity and political success are symbiotic. Leaders of the BR countries who sustain economic development can promote these accomplishments to further their political success. Therefore, such leaders might be expected to enthusiastically participate in the BRI. However, political will varies among the leaders of different states, and even the political will of the same leader may vary at different times given different political climates. Thus, it is impossible to say whether participating nations will retain their enthusiasm or even their participation in the BRI when different political parties come to power. Their policies may change dramatically along with a change in regime, which poses a serious risk to the BRI as a whole.

Geopolitical and economic reality is rarely orderly. In the real world, policies, priorities and allegiances among nations shift frequently, making sustained cooperative initiatives difficult to maintain. In Central Asia, the EAEU countries are also members of another Eurasian regional bloc - the CSTO. ${ }^{79}$ The EAEU and the CSTO can be combined to constitute a single de facto alliance with Russia as its core and driving force. ${ }^{80}$ Meanwhile, the Commonwealth of Independent States Free Trade Area ("CIS FTA") is a free trade area between Russia, Ukraine, Belarus, Uzbekistan, Moldova, Armenia, Kyrgyzstan, Kazakhstan and Tajikistan which "provides for free movement of goods within the territory of the CIS, non-application of import customs duties, non-discrimination, gradual decrease of export customs duties and abolishment of quantitative restrictions in mutual trade between the CIS FTA Member States." ${ }^{, 81}$ For these states, choosing between the existing integration agreements and China's BRI will inevitably require political trade-offs based on considerable political will. Even if nations initially opt to participate in the construction of the BR, they may easily change course due to political shifts, thus negating the achievements of the BRI. Moreover, some countries are concerned about China's BRI because the idea of integration would mean a zero-sum game in terms of less political and economic independence. Malaysian Prime Minister Mahathir Mohamad's attitude towards China's BRI is an example in Southeast Asia. ${ }^{82}$

Keeping these factors in mind, the current flexible ideology underpinning the 
BRI may not be the ideal model to build a stable and sustainable international system of alliances. Instead, China should format the BRI as a systematically planned national policy, generating legal documents that clearly define its specific scope, cooperation areas, cooperation mechanisms, dispute settlement methodologies and other specific mechanisms, and subsequently conclude an overarching "Belt and Road Convention" to replace existing bilateral free trade agreements and establish the BRI's implementing institutions. Doing so will establish a firmer foundation upon which to base development efforts, creating a certain and plausible international cooperation mechanism. ${ }^{83}$

\section{An Alternative to a Silk Road Union}

Systematic planning to create a formal BR cooperation mechanism is necessary to meet the severe challenges facing the initiative, including fluctuating international political will, shifting geopolitical attitudes and conflicting dispute resolution and administration mechanisms. To address these issues, China should improve the existing BR cooperation mechanism and seek to create a multilateral cooperation mechanism at the global level. ${ }^{84}$ China must cooperate with the BR countries to develop the basic principles of international law, maritime law and international economic law, thereby protecting China's overseas interests alongside the interests of participating nations, as well as promoting the public good. ${ }^{85}$

\section{A. Systematic Construction of the BR Cooperation Mechanism}

Pursuing the 'multilateralization' of the BRI will be a significant undertaking, as the Initiative presently includes 65 countries, 4.4 billion people and about 40 per cent of global GDP. However, seeking structured alignment through a formal agreement could maximize the major benefits of the BRI for participating countries, allowing them to improve their investment climate, technical standards and customs and logistics procedures. ${ }^{86}$ As the chief advocate and organizer of the BRI, China should further improve relevant policy documents, laws and regulations and foreign cooperation mechanisms to enable interested nations to more readily partner in this grand initiative. At the same time, China should also make efforts to explain the BRI in international legal language, clarifying and codifying its aims, connotation, organization, functions, 
cooperation areas, priority industries, promotion methodologies and dispute settlement mechanisms. HE expounded: "The function of international law lies in providing technical support and interpretation for the direction and objectives in international relations that have been defined by a country's political strategy and national interests. ${ }^{, 87}$ Bearing this principle in mind, in the process of developing international exchanges, China must rely on the institutional system of international law to promote such exchanges and cooperation efforts, developing its goals and ideas through the application of relevant international law. ${ }^{88}$ When seeking to establish the BRI as a relevant global force, to formulate international rules for the BRI is China's priority task. ${ }^{89}$ This also presents a strategic opportunity for China to improve its domestic laws, establish relevant bilateral and multilateral mechanism, and participate in the construction of the international legal system. Therefore, China should incorporate the practice of international law into the construction of the BRI to refine its international legal concepts and viewpoints. This will help to build a new international legal order as well as ground for Chinese international law. ${ }^{90}$

China should make efforts to create and implement international rules related to the BRI by means of concluding international treaties, establishing international organizations and ultimately creating a new international order, enabling China to become an advocate for a new international order based on enhanced global cooperation, economic and cultural development. ${ }^{91}$ Some international lawyers have proposed an international energy community ${ }^{92}$ or a Silk Road Union ${ }^{93}$ as structures for China to exercise international leadership in this way. These suggested initiatives, however, are still in their nascent phases. Nevertheless, some basic principles have been generally acknowledged as follows: (1) the BR cooperation mechanism should aim to promote international economic development by facilitating free trade and investment as well as equal opportunity and the right to development; (2) it must address in a strategic way the relationship between the legal systems in different BR countries, which are rooted in their culture and religion under international law; (3) it must adhere to market-oriented, government-driven and business-led development methodologies; and (4) it must pay close attention to the macro-economic policies of the BR countries and the micro-economic activities of their enterprises so that it can provide necessary support and protection for enterprises to compete in the international market. $^{94}$

Meanwhile, China should institutionalize international cooperation based on 
existing platforms. Of these, the BR Forum for International Cooperation held in May 2017 is the largest, highest-level multilateral diplomatic platform initiated and hosted by China. It produced 279 deliverable plans in the areas of policy, infrastructure, trade, financial and connectivity. Furthering these efforts, China should work to institutionalize the BR Forum for International Cooperation by setting up a liaison office to implement the Forum's follow-up activities ${ }^{95}$ and an advisory council to oversee regular forum activity. ${ }^{96}$ Also, China should integrate other platforms, including the Forum on China-Africa Cooperation ("FOCAC"), ${ }^{97}$ and establish a comprehensive legal and institutional framework with the ultimate goal of building these forums into an institutionalized multilateral cooperation mechanism.

Regarding the possible overlaps and even conflicts between the BR cooperation mechanism and other multilateral cooperation schemes, China should "make full use of the existing international mechanisms and continuously strengthen community awareness of these international mechanisms and their member states, and actively guide these mechanisms to link up with the BR in terms of functions, development strategies and actions, thus injecting new connotations and vitality into it." ${ }^{, 8}$ In the area of trade and investment, for example, China should actively promote the WTO's Trade Facilitation Agreement in the region, ${ }^{99}$ ensuring that developing and leastdeveloped countries receive the assistance they need. Moreover, China should draft the Strategic Action Framework for Trade and Investment Facilitation of the Silk Road Economic Belt to ensure a functional connection with organizations such as the WTO, the ASEAN, the APEC and the World Customs Organization. It should facilitate, as far as possible, the measures providing the greatest common good, such as reducing tariffs and non-tariff barriers, adopting standardized processes, speeding up the flow of transportation and people and simplifying customs procedures. ${ }^{100}$

\section{B. Economic Cooperation as the Greatest Common Denominator}

Multilateral cooperation within the BRI must be streamlined to induce economic cooperation. Scholars have suggested that: "Development is still the main theme of the world today. The BRI is in alignment with the common interest of the international community." ${ }^{, 101}$ All nations have certain similarities. For instance, all countries, regardless of their level of development and political system, have a strong incentive to eradicate poverty and develop their economies; no country would accept another country's interference in its internal affairs or threats to its security. 
India is a noticeable example of how ambivalent views regarding the BRI may evolve within a nation on the basis of these natural interests. Biased by "dread of Chinese hegemony," "many individuals in the Indian security establishment have positioned China as a greater menace than ever before." ${ }^{\text {102 }}$ As a result, many in the Indian government object to the China-Pakistan Economic Corridor, which, according to some Indian scholars, challenges India's sovereignty. ${ }^{103}$ There are also concerns regarding increasing Chinese naval activities in the Indian Ocean, as well as Chinese geo-strategic influence on regions claimed by India. ${ }^{104}$ Meanwhile, on the other end of the spectrum, many Indians hold liberal views regarding China's BRI, urging their country to participate the BRI to "improve Indian connectivity to major markets and resources," "especially [its] integration with Eurasian economy," seeing such participation as a way to fulfil India's increasing energy and infrastructure demands and to build up trust between India and China. ${ }^{105}$ As can be seen through this example, understanding different countries' unique perceptions of the BRI and finding common grounds for cooperation will be the first step in the successful implementation of the BRI.

The greatest common denominator of cooperation among all BR countries -their quintessential shared interest - is not to engage in security cooperation, but to develop their economy and achieve a win-win scenario. ${ }^{106}$ This emphasis on economic matters is not only because the existing security cooperation among BR countries is characterized by contradictions and a lack of basic consensus, but because the maintenance of international peace and security and the development of friendly relations among nations falls under the purview of the UN and its legal system. ${ }^{107}$ Since all BR countries are the UN members, relevant issues can be addressed in accordance with the purposes and principles of the UN Charter. China is willing to "provide more international public goods for humanitarian purposes: for example, an international rescue team for natural disasters such as earthquakes, tsunami and typhoons or an international medical team for various major diseases and infectious diseases." ${ }^{, 108}$ However, issues involving peacekeeping, counter-terrorism, anti-piracy activities, humanitarian assistance and military security must be completed within the framework of the UN. If such issues become entangled with the aims of the BRI, it will inevitably dilute the economic cooperation and culture exchanges between China and the BR countries, potentially even leading to political and military disputes. Therefore, China should insist that the cooperation fostered under the BRI not involve security issues. 
Notably, however, the proposed cooperation regarding maritime law enforcement is not a security issue. Instead, it constitutes a joint emergency mechanism for maritime law enforcement. Its purpose is to maintain the safety of maritime economic activities and promote maritime cooperation in an orderly manner. For example, China and the ASEAN approved the Guidelines for a Senior Diplomats' Hotline for Maritime Emergencies to enhance the level of cooperation and mutual trust on maritime affairs. The China Coast Guard has signed MOUs on cooperation with Vietnam and the Philippines to establish law enforcement cooperation mechanisms, such as the Joint Committee of Coast Guards on Maritime Cooperation. China has also strengthened dialogue with the coast guards of India, Bangladesh and Myanmar, and carried out institutionalized cooperation with Pakistan Maritime Security Agency to jointly combat maritime crime. ${ }^{109}$ Given the challenges of security entanglement among partner nations, China is justifiably cautious about cooperating on maritime law enforcement and has avoided any military security claims. For example, China has never used this platform to reaffirm its territorial sovereignty and maritime rights and interests in the SCS, or to advance its objection to military use of the exclusive economic zone. ${ }^{110}$

In short, the ultimate goal of the BRI is not to create an economic community, a political community, a military security community, a customs union or a single currency zone. Rather, it seeks to foster a regional human community of shared destiny. ${ }^{111}$ In pursuing the BRI, China will not interfere in other countries' internal affairs, export its own social system and model of development or impose its will on others. It vows to neither resort to outdated geopolitical manoeuvring, nor form any group detrimental to stability. ${ }^{12}$ The cooperation proposed under the BRI is intended to promote economic and cultural development, exclusive of military security, which is consistent with China's long-standing policy of non-alignment. ${ }^{113}$

\section{The Urgent Need for a Dispute Settlement Mechanism}

The most critical issue at this moment in the BRI's implementation trajectory is the lack of a clear dispute settlement framework. The existing multilateral dispute settlement mechanisms have a limited effect on the BR. For example, the WTO dispute settlement mechanism cannot be applied to non-WTO countries; the Convention on the Settlement of Investment Disputes between States and Nationals of Other States primarily provides the procedural rules for resolving investment disputes 
between investors and host countries; the Convention Establishing the Multilateral Investment Guarantee Agency mainly deals with disputes involving overseas investment insurance; and the Energy Charter Treaty does not directly protect Chinese investors, as China is currently only an observer state. ${ }^{114}$ Therefore, it is imperative to establish a bilateral dispute settlement mechanism in order to meet the challenges which will inevitably surface as the BRI progresses. ${ }^{115}$

China should make full use of bilateral investment treaties ("BITs") to protect its overseas investment. Because China has currently a limited number of regional FTAs $^{116}$ and their investment rules are as good as those of BITs, various BITs between China and countries along the road comprise the main tools to protect China's overseas investments. ${ }^{117}$ This process is already under way. Since 1982, China has negotiated and signed BITs with 129 countries, 58 of which are along the BR. ${ }^{118}$ China should undertake a systematic analysis of all BITs and modify, if necessary, their investment protection provisions. For example, it may be necessary to update the definition of 'investment' and establish principles regarding indirect expropriation, fair and equitable treatment of investors and umbrella clauses in order to strengthen treaty protection for China's overseas investments. ${ }^{119}$

Additionally, China should actively engage in judicial cooperation and exchange with the BR countries. As the BRI progresses, more cases involving foreign parties will inevitably arise, which will involve a wide variety of matters, including criminal, civil and commercial cases; maritime law; international commercial and maritime arbitrations; free trade zones, etc. In light of this extensive array of potential legal conflicts, it is difficult to establish a unified dispute settlement mechanism. ${ }^{120}$ The most feasible approach at present is to strengthen judicial cooperation between China and the BR countries, and to promote the convergence of national laws. ${ }^{121}$ To this end, China should conclude more bilateral judicial cooperation agreements and build a workable bilateral judicial assistance mechanism. ${ }^{122}$

To achieve this goal, China should first seek to conclude mutual judicial assistance agreements with each BR country, working to improve the legal situation throughout the region. This could include re-examining systems for ascertaining the identities of parties, conducting overseas evidence reviews and testifying in court by overseas witnesses, so as to facilitate smooth litigation between Chinese and foreign parties. China should emphasize the need for mutual recognition and enforcement of judicial decisions between the BR countries. For those countries which has not yet concluded a 
judicial assistance agreement with China, Chinese courts should take the lead to grant judicial assistance to litigants from those countries with a view to promoting reciprocal judicial assistance in the future. For those countries which has concluded a judicial assistance agreement with China, Chinese courts should strictly follow that agreement, promptly handling requests for judicial assistance. The efficient, effective litigation practice will create a supportive rule-of-law environment to underpin the construction of the BRI. ${ }^{123}$

Moreover, Chinese courts should accurately and appropriately apply international treaties, conventions and foreign laws. Chinese courts should undertake an indepth study of the international treaties on trade, investment, finance and maritime transportation concluded by the BR countries, and interpret treaty terms in strict accordance with the provisions of the Vienna Convention on the Law of Treaties so as to strengthen the unity, stability and predictability of international treaties and conventions applied at trial. In accordance with the provisions of the Law of the Application of Law for Foreign-Related Civil Relations, Chinese courts should comprehensively consider foreign factors related to legal matters, fully respect the litigant's right to choose applicable law, accurately identify and apply foreign laws. ${ }^{124}$

Finally, China should support the development of diversified dispute settlement mechanisms when building the BRI. Complainants must have the right to resolve disputes through mediation, arbitration and other non-litigation approaches based on their own political, legal, cultural and religious backgrounds. China should pay special attention to settling disputes through mediation and arbitration. The SPC of China is already taking steps to address this need, stating that "Chinese courts should further promote the perfection of and linkages between different types of mediation, such as commercial, arbitration, administrative, industrial and judicial, taking full advantage of various methods of solving disputes along the BR to meet the diverse needs of Chinese and foreign litigants." ${ }^{125}$ Following this guidance, Chinese courts should strengthen the judicial review system and ensure the recognition and implementation of arbitral awards from the BR countries, in accordance with relevant laws and the Convention on the Recognition and Enforcement of Foreign Arbitral Awards. ${ }^{126}$

China's newly established international commercial courts and committee of international commercial experts can only be used to resolve international commercial disputes between equal commercial entities. ${ }^{127}$ However, the implementation of the BRI, whose infrastructure projects demand immense investments and decades-long 
construction projects, has already faced significant challenges, including several obstacles of agreements made by foreign governments. For example, Malaysian Prime Minister Mahathir Mohamad cancelled two major BR projects soon after he came into power. ${ }^{128}$ The only way to prevent Chinese enterprises from suffering significant losses because of political gamesmanship is to make each country bear legal responsibilities for its actions.

Absent either a bilateral or multilateral dispute settlement agreement, China should appropriately resolve relevant disputes through consultation in accordance with the basic principles of international law. The "Five Principles of Peaceful Coexistence" is for example a China's expression of the basic principles of international law. These Principles are not only the cornerstone of the country's diplomacy, but also the basis for its great achievements in political, social and economic reform and international engagement. ${ }^{129}$ Given the success fostered by the implementation of these ideals, China should codify the principles for a dispute settlement mechanism of the BRI, allowing it to serve as a basis for bilateral negotiations on related disputes.

\section{Conclusion}

China's promotion of the BRI is not intended to develop its domestic economy by exporting excess capacity to international markets. Rather, it is meant to achieve a win-win situation promoting increased economic development, infrastructure construction, employment and interconnection among interested nations, thus building "a human community with shared destiny." non-systematic cooperation mechanism with strong roots in China's own path towards economic development. However, this non-systematic mechanism is not aligned with the conventional model of international cooperation mechanism development, which cannot adequately manage the many contradictions.

The traditional approach to regional integration is to "use multilateral treaties to remove legal and institutional barriers to trade and investment, and to create legally binding rules, standards and dispute resolution mechanisms to create a flat open space for private sector actors. ${ }^{, 131}$ At present, the BRI rejects rigid institutionalization in favour of a more flexible approach to development. However, as a new formula for global governance, the BRI must be pushed forward in a way 
that is both innovative and systematic. China should negotiate with the BR countries to conclude a comprehensive regional Silk Road Convention, according to which bilateral cooperation agreements for specific fields or projects may be concluded. ${ }^{132}$ It is imperative to establish a comprehensive legal mechanism at the national and international levels and a uniform institutional structure for the implementation and the success of the BRI.

\section{REFERENCES}

1. NDRC, Ministry of Foreign Affairs, and Ministry of Commerce with the authorization of the State Council, the People's Republic of China, The Vision and Actions on Jointly Building Silk Road Economic Belt and 21st-Century Maritime Silk Road, The Belt and Road Portal (Mar. 28, 2015), available at https://eng.yidaiyilu.gov.cn/qwyw/qwfb/1084. $\mathrm{htm}$.

2. Id.

3. Xi Jinping, The Report Delivered at the 19th National Congress of the Communist Party of China, China DAILY, Oct. 18, 2017, available at http://www.chinadaily.com.cn/interface/ flipboard/1142846/2017-11-06/cd_34188086.html.

4. Supra note 1.

5. Zhipeng He, A Chinese Plan on International Rule of Law: A Perspective of Global Governance on the BRI [国际法治的中国方案: “一带一路” 的全球治理视角], 25(5) PAC. J. [太平洋学报] 2 (2017).

6. Ming Li, International Law and the Study on the BRI [国际法与 “一带一路” 研究], 37(1) L. SCI. MAG. [法学杂志] 11, 16 (2016).

7. Zewei Yang, Designing the Energy Community between China and its Neighbors: Legal Fundamentals and Achieving Approaches [中国与周边能源共同体的构建: 法律基础与实 现路径], 1(5) Wuhan U. INT'L. Rev. [武大国际法评论] 27-37 (2017).

8. Z. Kembayev, Regional Integration in Eurasia: The Legal and Political Framework, 41 Rev. Cent. East Eur. L. 157-94 (2016); Z. Kembayev, Towards a Silk Road Union, 15 China J. InT'L. L. 691-2 (2016).

9. In February 2015, China established a leading group for Promoting the BRI, whose office is under the NDRC.

10. The Office of the Leading Group for Promoting the BRI, The Action Plan on BR Standard Connectivity (2018-20) [标准联通共建 “一带一路” 行动计划 (2018-2020年)], The Belt and Road Portal (Dec. 22, 2017), available at http://www.yidaiyilu.gov.cn/zchj/ qwfb/43480.htm. 
11. PRC Ministry of Culture, Ministry of Culture's Action Plan on BR Culture Development (2016-20) [文化部 “一带一路” 文化发展行动计划], The Belt and Road Portal (Jan. 2017), available at http://www.yidaiyilu.gov.cn/wcm.files/upload/CMSydylgw/201703/ 201703010312012.pdf.

12. PRC Ministry of Culture, Articles of Agreement of the Asian Infrastructure Investment Bank [亚洲基础设施投资银行协定], The Belt and Road Portal (June 2015), available at http://www.yidaiyilu.gov.cn/wcm.files/upload/CMSydylgw/201702/201702170558058. pdf.

13. PRC Ministry of Culture, Guiding Principles on Financing the Development of the BR, The Belt and Road Portal (May 2017), available at http://wjb.mof.gov.cn/pindaoliebiao/ gongzuodongtai/201705/P020170515761133537061.pdf.

14. PRC Ministry of Environmental Protection, The BR Ecological and Environmental Cooperation Plan, The Belt and Road Portal (May 2017), available at http://www. yidaiyilu.gov.cn/wcm.files/upload/CMSydylgw/201705/201705140543014.pdf.

15. Ministry of Environmental Protection, Ministry of Foreign Affairs, the NDRC, and Ministry of Commerce of China, Guidance on Promoting Green BR, Ministry of Ecology and Environment of China (June 28, 2017), available at http://english.mee.gov.cn/ Resources/Policies/policies/Frameworkp1/201706/t20170628_416864.shtml.

16. The NDRC and PRC State Oceanic Administration, Vision for Maritime Cooperation under the BRI, The Belt and Road Portal (June 2017), available at http://www.yidaiyilu. gov.cn/wcm.files/upload/CMSydylgw/201706/201706200153032.pdf.

17. The SPC of China, The Several Opinions of the SPC on Providing Judicial Services and Safeguards for the Construction of the BR by People's Courts (SPC issuance No. 9), People's Court Daily (July 8, 2015), available at http://enccmt.court.gov.cn/ChinaForei gnRelatedCommercialTrial/2017-02/20/c_59482.htm.

18. The SPC of China, Model Cases regarding Providing Judicial Services and Safeguards by the SPC for Construction of the BR [人民法院为 “一带一路” 建设提供司法服务和保障 的典型案例] (Jul. 7, 2015), available at http://www.court.gov.cn/zixun-xiangqing-14897. html; Second Group of Model Cases Involving Construction of the BR Published by the SPC [第二批涉 “一带一路” 建设典型案例] (May 15, 2017), available at http://www. court.gov.cn/zixun-xiangqing-44722.html.

19. Supra note 17.

20. PRC General Office of the Communist Party Central Committee and the General Office of the State Council, Opinion Concerning the Establishment of the BR International Commercial Dispute Resolution Mechanism and Institutions (June 27, 2018), available at $\mathrm{http}: / /$ cicc.court.gov.cn/html/1/219/208/210/819.html.

21. The SPC of China, Regulations on Several Issues regarding the Establishment of International Commercial Courts [最高人民法院关于设立国际商事法庭若干问题的规定] (June 25, 2018), available at http://www.court.gov.cn/zixun-xiangqing-104602.html. 
22. The SPC of China, Top Court Sets up International Commercial Expert Committee (Aug. 27, 2018), available at http://english.court.gov.cn/2018-08/27/content_36839651.htm.

23. Model service guidelines for overseas economic and trade cooperation zones, insurance industry, and taxation have been issued by relevant ministries. See, e.g., PRC Ministry of Commerce, Notice of the Ministry of Commerce on Issuing the Model Service Guidelines for Overseas Economic and Trade Cooperation Zones [境外经贸合作区服务指南范本 ], The Belt and Road Portal (Aug. 4, 2015), available at http://www.yidaiyilu.gov.cn/ zchj/zcfg/6063.htm; China Insurance Regulatory Commission, Guiding Opinions of the China Insurance Regulatory Commission on Services of the Insurance Industry for the Building of the BR [中国保监会关于保险业服务 “一带一路” 建设的指导意见], The Belt and Road Portal (Apr. 27, 2017), available at http://www.yidaiyilu.gov.cn/zchj/ zcfg/11952.htm; State Administration of Taxation, Notice of the State Administration of Taxation on Further Improving Tax Services for the Construction of the BR [ 国家税务 总局关于进一步做好税收服务 “一带一路” 建设工作的通知] (Apr. 24, 2017), available at http://www.chinatax.gov.cn/n810341/n810755/c2584841/content.html.

24. The Belt and Road Portal has collected the main policy documents on foreign investment in order to provide continuous assistance for Chinese enterprises to 'go global'. For details, see The Policy Documents on Enterprise’s Foreign Investment [企业对外投资政策文件汇 编] (Dec. 28, 2017), available at http://www.yidaiyilu.gov.cn/zchj/zcfg/41379.htm.

25. Office of the Leading Group for Promoting the BRI, The Belt and Road Initiative Progress, Contributions and Prospects (2019), The Belt and Road Portal (Apr. 22, 2019), available at https://www.yidaiyilu.gov.cn/wcm.files/upload/CMSydylgw/201904/201904220254037. pdf.

26. NDRC, Guidelines on Construction of China-Mongolia-Russia Economic Corridor [ 建设 中蒙俄经济走廊规划纲要], The Belt and Road Portal (Sept. 13, 2016), available at http:// www.yidaiyilu.gov.cn/wcm.files/upload/CMSydylgw/201702/201702150500007.pdf.

27. NDRC, The Cooperation Plan on Dovetailing the Silk Road Economic Belt and Nurly Zhol (Bright Road) [中华人民共和国政府和哈萨克斯坦共和国政府关于 “丝绸之路 经济带” 建设与 “光明之路” 新经济政策 对接合作规划], The Belt and Road Portal (Sept. 2, 2016), available at https://www.yidaiyilu.gov.cn/wcm.files/upload/CMSydy lgw/201702/201702160515014.pdf. See also PRC Ministry of Foreign Affairs, Carry Forward Silk Road Spirit and Write a New Chapter for Cooperation (June 10, 2017), available at http://www.fmprc.gov.cn/mfa_eng/zxxx_662805/t1469852.shtml.

28. Agreement on Economic and Trade Cooperation between the EAEU and China (May 17, 2018), available at http://eec.eaeunion.org/ru/act/trade/dotp/sogl_torg/Documents/ Forms/Allitems.aspx.

29. PRC Ministry of Environmental Protection, The BR Ecological and Environmental Cooperation Plan, The Belt and Road Portal (May 2017), available at http://www. yidaiyilu.gov.cn/wcm.files/upload/CMSydylgw/201705/201705140543014.pdf; PRC 
Ministries of Environmental Protection, Foreign Affairs, Commerce and the NDRC, Guidance on Promoting Green BR, Ministry of Ecology and Environment of China (June 28, 2017), available at http://english.mee.gov.cn/Resources/Policies/policies/ Frameworkp1/201706/t20170628_416864.shtml; The NDRC and the State Oceanic Administration of China, Vision for Maritime Cooperation under the BRI, The Belt and Road Portal (June 2017), available at http:/www.yidaiyilu.gov.cn/wcm.files/upload/ CMSydylgw/201706/201706200153032.pdf. For details on policy documents and implementation plans issued by relevant governmental ministries and commissions, see The Belt and Road Portal (Policies and Regulations), available at https://eng.yidaiyilu.gov. cn/info/iList.jsp?cat_id=10062.

30. Supra note 1.

31. Id.

32. PRC Ministries of Agriculture, Commerce, Foreign Affairs and the NDRC, Vision and Action on Jointly Promoting Agricultural Cooperation on the Belt and Road [共同推进 “一 带一路” 建设农业合作的愿景与行动] (May 2017), available at http://jiuban.moa.gov.cn/ zwllm/zwdt/201705/t20170512_5604724.htm.

33. Id.

34. Supra note 1.

35. See China Railway Express [中欧班列], The Belt and Road Portal (July 20, 2018), available at http://www.yidaiyilu.gov.cn/zchj/rcjd/60645.htm.

36. See Intergovernmental Agreement of the SCO Member States on the Facilitation of International Road Transport (Sept. 12, 2014), available at http://eng.sectsco.org/ load/207681along the Asian Highway Network (Dec. 8, 2016), available at https://www. unescap.org/sites/default/files/Intergovernmental-Agreement-on-International-RoadTransport-along-the-Asian-Highway-Network-English-language.pdf.

37. Office of the Leading Group for Promoting the BRI, Building the BR: Concept, Practice and China's Contribution [共建 “一带一路” 带理念、实践与中国的贡献], The Belt and Road Portal (May 2017), available at http://www.yidaiyilu.gov.cn/wcm.files/upload/CM Sydylyw/201705/201705110537027.pdf.

38. Supra note 25.

39. Id.

40. Supra note 37.

41. Id.

42. Id.

43. See, e.g., Gwadar port creates economic magic with Chinese help, China Daily, Dec. 12, 2018, available at http://www.chinadaily.com.cn/a/201811/12/WS5be8d62ba310eff303287f6c. html; Staff reporter, Outlook positive as Hambantota Port grows with opportunities for Sri Lankans, Xinhuanet, Dec. 12, 2018, available at http:/www.xinhuanet.com/ english/2019-12/24/c_138655160.htm; Staff reporter, Malacca, 'China's gateway to $S$-E 
Asia,' Straits Times, Apr. 16, 2017, available at https://www.straitstimes.com/asia/ se-asia/malacca-chinas-gateway-to-s-e-asia; Staff reporter, China, Myanmar sign port deal after years of negotiations, Global Times, Nov. 8, 2018, available at http://www. globaltimes.cn/content/1126664.shtml.

44. Supra note 8, at 691.

45. Z. Kembayev, The Emerging Eurasian Union: Problems and Perspectives (July 18, 2014), available at https://static.uni-graz.at/fileadmin/rewi-zentren/Reees/Projekte/Zhenis _ Kembayev.pdf.

46. For details on "Central Asia plus Japan" Dialogue, see Ministry of Foreign Affairs of Japan, “Central Asia plus Japan” Dialogue, available at https://www.mofa.go.jp/region/ europe/dialogue/index.html.

47. B. Jaipragas, Why Is the US Calling Asia-Pacific the Indo-Pacific? Donald Trump to “clarify,” South China Morning Post, Nov. 7, 2017, available at http://www.scmp.com/ week-asia/politics/article/2118806/why-us-calling-asia-pacific-indo-pacific-trumpclarify.

48. Staff reporter, India, Vietnam to Sign Deal for Oil Exploration in South China Sea Despite Protest by China, DNA India (Oct. 27, 2014), available at http://www.dnaindia.com/ india/report-india-vietnam-to-sign-deal-foroil-exploration-in-south-china-sea-despiteprotest-by-china-2029677.

49. Wenhong Xu, Russia, Central Asia Accept BRI Gainful, China Daily, Aug. 23, 2018, available at http://www.chinadaily.com.cn/a/201808/23/ WS5b7df4cba310add14f3873c6.html.

50. Staff reporter, China-Russia Joint Declaration of Further Deepening the Comprehensive Strategic Partnership of Coordination [中华人民共和国和俄罗斯联邦关于进一步深化 全面战略协作伙伴关系的联合声明], XINHUANET, July 5, 2017, available at http://www. xinhuanet.com//world/2017-07/05/c_1121263941.htm.

51. PRC Ministry of Commerce, China and Russia Sign the Joint Declaration of the Joint Feasible Studies on Completing Eurasian Economic Partnership Agreement (June 9, 2018), available at http://english.mofcom.gov.cn/article/newsrelease/significantne ws/201806/20180602754961.shtml.

52. Ran Guo, Legal Basis of China's Claim over the Huangyan Island, 6 J. EAST Asia \& INT'L L. 531-52 (2013); Sino-Vietnam Dispute over Hydrocarbon Resources Exploration in Nansha Waters after the South China Sea Arbitration, 47 Hong Kong L. J. 951-85 (2017).

53. Id. at 978.

54. H. Clinton, Press Statement on Vietnam's National Day (Aug. 31, 2012), available at https://2009-2017.state.gov/secretary/20092013clinton/rm/2012/08/197209.htm. This position was reaffirmed by the Trump administration at the 6th US-ASEAN Summit and the 33rd East Asia Summit. See P. Murphy, The United States and ASEAN: Forward Together (Nov. 13, 2018), available at https://blogs.state.gov/stories/2018/11/13/en/united- 
states-and-asean-forward-together.

55. Commission on Security and Cooperation in Europe, The New Silk Road Strategy: Implications for Economic Development in Central Asia (July 31, 2013), available at http://www.csce.gov/sites/helsinkicommission.house.gov/files/The $\% 20 \mathrm{New} \% 20$ Silk\%20Road\%20Strategy.pdf.

56. B. Naughton, What Will the TPP Mean for China?, ForeIGN PoL'y, Oct. 7, 2015, available at http://www.foreignpolicy.com/2015/10/07/china-tpp-trans-pacific-partnershipobama-us-trade-xi. See also M. Kuo, CPTPP and Leadership in the Global Trade System, Diplomat, Apr. 10, 2018, available at https://thediplomat.com/2018/04/cptpp-andleadership-in-the-global-trade-system.

57. Supra note 1, at V (Cooperation Mechanisms).

58. Id. at II (Principles).

59. On March 17, 2017, the UN Security Council unanimously adopted Resolution 2344, calling on the international community to strengthen regional economic cooperation through the BRI. See also Ufa Declaration of Heads of Member States of SCO (July 10, 2015), available at $\mathrm{http}: / /$ eng.sectsco.org/load/200119.

60. Supra note 5.

61. Supra note 17.

62. Supra note 1, at V (Cooperation Mechanisms).

63. C. Guluzian, Making Inroads: China's New Silk Road Initiative, 37 Cато J. 145 (2017).

64. Tao Yang, International Law and the Challenges Faced by the BR [“一带一路”建设面临 的挑战及国际法思考], 37 J. KASHGAR U. [喀什大学学报] 42-5 (2016).

65. Xiaohui Zhang, Legal Risk Management of Overseas Investment under the BRI [解读一带 一路新形势下境外投资的法律风险管理], 1 International PROJeCt Contracting \& LabouR SERVICE [国际工程与劳务] 35-6 (2015).

66. Supra note 64.

67. Xueping Li, Cooperation Mechanism of the BR: Legal Defects, Challenges and Solutions [“一带一路” 的合作机制: 法律缺陷、复杂挑战与应对策略] 421 MonTHLY THEORY [理论月 刊] 5-9 (2017).

68. Supra note 1, Preface.

69. Lingliang Zeng, Conceptual Analysis of China's BRI: A Road towards a Regional Community of Common Destiny, 15 CHINESe J. INT'L L. 538 (2016).

70. Supra note 1, V (Cooperation Mechanisms).

71. Supra note 63, at 135 .

72. Supra note 67.

73. Supra note 69 , at 539.

74. Tao Li \& Zuoli Jiang, Implication of the Asian Infrastructure Investment Bank for Global Financial Governance: Accommodation or Confrontation?, 9 Tsinghua China L. Rev. 142 (2016), available at https://papers.ssrn.com/sol3/papers.cfm?abstract_id=2913988. 
75. Supra note 5 , at 7.

76. A thought experiment is a device with which one performs an intentional, structured process of intellectual deliberation in order to speculate, within a specifiable problem domain, about potential consequents (or antecedents) for a designated antecedent (or consequent). See L. Yeates, Thought Experimentation: A Cognitive Approach (July 2004) (Graduate Diploma in Arts dissertation, University of New South Wales) at 150, available at https://archive.org/details/TECA2004/mode/2up.

77. Supra note 5, at 5.

78. Supra note 69 , at 527.

79. Supra note 8 , at 691.

80. Id. at 168 .

81. Id. at 183 .

82. J. Geddie, Malaysia Renegotiating Terms of Major Belt-and-Road Rail Project: PM Mahathir, ReUTERs, May 26, 2018, available at https://uk.reuters.com/article/us-malaysiapolitics-projects/malaysia-renegotiating-terms-of-major-belt-and-road-rail-project-pmmahathir-idUKKCN1IR0FM. See also A. Erickson, Malaysia Cancels Two Big Chinese Projects, Fearing They Will Bankrupt the Country, Wash. Post, Aug. 21, 2018, available at http://www.washingtonpost.com/world/asia_pacific/malaysia-cancels-two-massivechinese-projects-fearing-they-will-bankrupt-the-country/2018/08/21/.

83. International lawyers have suggested that China and other BR countries should negotiate and conclude "a comprehensive regional or multilateral BR agreement" or establish "the Silk Road Union.” See supra note 69, at 532; supra note 8, at 691-9.

84. Supra note 69 , at 541.

85. Supra note 6.

86. B. Hofman, China One Belt One Road Initiative: What We Know Thus Far, ChinaGoAbroad (Apr. 12, 2015), available at http://www.chinagoabroad.com/en/article/china-s-one-beltone-road-initiative-what-we-know-thus-far.

87. Supra note 5 , at 4 .

88. R. Mushkat, State Reputation and Compliance with International Law: Looking through a Chinese Lens, 10 ChINESE J. ItN'L L. 703-37 (2011).

89. Yongping Xiao, The International Law for the BR and the Role of China's Courts [“一带 一路”战略需要的国际法及我国法院的作用], 15 CHINA TRIAL [中国审判] 15 (2015).

90. Supra note 6, at 13 .

91. Supra note 5, at 3.

92. Supra note 7.

93. Supra note 8, at 692.

94. Supra note 67.

95. Xi Jinping, Work Together to Build the Silk Road Economic Belt and the 21st Century Maritime Silk Road-Speech at the Opening Ceremony of the BR Forum for International 
Cooperation, Xinhuanet, May 14, 2017, available at http://www.xinhuanet.com/ english/2017-05/14/c_136282982.htm.

96. The BR Forum for International Cooperation, List of Deliverables of the BR Forum for International Cooperation, CHINA DAILy, May 16, 2017, available at http://www. chinadaily.com.cn/china/2017-05/16/content_29359377.htm.

97. The 2018 Beijing Summit of the FOCAC adopted the Beijing Declaration-Toward an Even Stronger China-Africa Community with a Shared Future and the FOCAC Beijing Action Plan (2019-2021) on September 4, 2018. See Beijing Declaration, Action Plan Adopted at FOCAC Summit, The Belt and Road Portal (Sept. 5, 2018), available at https://eng. yidaiyilu.gov.cn/qwyw/rdxw/65061.htm.

98. Supra note 64.

99. The Trade Facilitation Agreement entered into force on February 22, 2017. See Ratifications List, available at http://www.tfafacility.org/ratifications.

100. Supra note 64.

101. Supra note 6, at 11.

102. H. Khan \& I. Khalid, New Delhi Response to Beijing "BRI” Project: A Lucid Connection with Chinese "String of Pearls", 25 J. Pol. Stud. 243-254 (2018).

103. D. Chaudhury, China Wants India in One-Belt-One-belt meet: India remains wary, InDia Times, Jan. 7, 2017, available at https://economictimes.indiatimes.com/news/ politics-and-nation/china-wants-india-in-one-belt-one-road-meet-india-remains-wary/ articleshow/56383009.cms. See also supra note 102, at 247.

104. Supra note 102, at 248-9.

105. Id.

106. The BRI may become one of the cornerstones of Asian economic growth and integration, and eventually a closer political and security cooperation framework among states. However, the pathway to this scenario is long and fraught with obstacles. See generally R. Ghiasy \& Jiayi Zhou, The Silk Road Economic Belt: Considering Security Implications and EU-China Cooperation Prospects (2017), available at https://www.sipri.org/sites/ default/files/The-Silk-Road-Economic-Belt.pdf.

107. U.N Charter arts. 1, 24-26 \& 39-51. China should work within the UN and its legal system, instead of creating a new mechanism.

108. Supra note 6, at 17.

109. Supra note 37.

110. Supra note 6, at 16.

111. Supra note 69.

112. Supra note 95.

113. For details on China's non-alignment policy, see Yusheng Wang, Should China Abandon Non-Alignment?, People's Daily, Nov. 4, 2012, available at http://en.people. $\mathrm{cn} / 102774 / 8004263 . \mathrm{html}$. 
114. Jingdong Liu, Building Fair and Reasonable Dispute Settlement Mechanism of the BRI [构 建公正合理的 “一带一路” 争端解决机制], 25 PAC. J. [太平洋学报] 16 (2017).

115. Hao-wen Wu, The Mode Selection of the Dispute Settlement Mechanism for the BRI ["一 带一路” 倡议争端解决机制的模式选择与构建], 34 J. SHENZHEN U. [深圳大学学报] 74-8 (2017); Chao Zhang \& Xiao-ming Zhang, Study on International Dispute Settlement Mechanism of BR Strategy [“一带一路” 战略的国际争端解决机制研究], 2 SE. AsIAN AFF. [南洋问题研究] 24-34 (2017).

116. China has concluded 16 FTAs with 24 countries and regions. See also Shaohua Sun, More FTAs Due in 2018 [明年自贸区有望迎成果 “丰收年”], ECON. InFormation DAILY [经济参考报], Dec. 27, 2017, available at http://dz.jjckb.cn/www/pages/webpage2009/ html/2017-12/27/content_39433.htm.

117. Supra note 64 .

118. UNCTAD, IIA database, China-Bilateral Investment Treaties, available at http://www. investmentpolicyhub.unctad.org/IIA/CountryBits/42\#iiaInnerMenu. See also Tingting Deng \& Meiyu Zhang, The Treaty Protection of Chinese Overseas Investment under the $B R I$ [“一带一路” 倡议下中国海外投资的条约保护], 22 J. CENT. S. U. [中南大学学报] 36 (2016).

119. Id. See also Jie (Jeanne) Huang, Silk Road Economic Belt: Can Old BITs Fulfil China's New Initiative?, 50 J. World Trade 733-54 (2016).

120. Supra note 64.

121. Supra note 89 , at 15.

122. By February 2018, China had signed 19 treaties on mutual judicial assistance in civil and criminal matters; 41 treaties on criminal judicial assistance; and 18 treaties on judicial assistance in civil and commercial matters. See PRC Ministry of Foreign Affairs, China's Treaties on Judicial Assistance and Extradition (Feb. 2018), available at http://www. fmprc.gov.cn/web/ziliao_674904/tytj_674911/wgdwdjdsfhzty_674917/t1215630. shtml.

123. Supra note 17.

124. Id.

125. Id.

126. Id.

127. Regulations on Several Issues regarding the Establishment of International Commercial Courts, arts. 2-3.

128. Supra note 82.

129. Supra note 6, at 12.

130. Supra note 63, at 138.

131. D. Arase, China's Two Silk Roads: Implications for Southeast Asia, 2 ISEAS PersPective 405 (2015).

132. Supra note 69 , at 540. 
国家税务总局关于进一步做好税收服务 “一带一路” 建设工作的通知] (Apr. 24, 2017), available at http://www.chinatax.gov.cn/ n810341/n810755/c2584841/content.html.

24 The Belt and Road Portal has collected the main policy documents on foreign investment in order to provide continuous assistance for Chinese enterprises to 'go global'. For details, see The Policy Documents on Enterprise' s Foreign Investment [企业对外投资政策文件汇编] (Dec. 28, 2017), available at http://www.yidaiyilu.gov.cn/zchj/zcfg/41379.htm.

25 Office of the Leading Group for Promoting the BRI, The Belt and Road Initiative Progress, Contributions and Prospects (2019), The Belt and Road Portal (Apr. 22, 2019), available at https://www.yidaiyilu.gov.cn/wcm.files/upload/CMSydylgw/2O1 904/201904220254037.pdf.

26 NDRC, Guidelines on Construction of China-Mongolia-Russia Economic Corridor [建设中蒙俄经济走廊规划纲要], The Belt and Road Portal (Sept. 13, 2016), available at http://www.yidaiyilu.gov.cn/wcm.files/upload/CMSydylgw/201702/2017021505 00007.pdf

27 NDRC, The Cooperation Plan on Dovetailing the Silk Road Economic Belt and Nurly Zhol (Bright Road) [中华人民共和国政 府和哈萨克斯坦共和国政府关于 “丝绸之路经济带” 建设与 “光明之路” 新经济政策 对接合作规划], The Belt and Road Portal (Sept. 2, 2016), available at https://www.yidaiyilu.gov.cn/wcm.files/upload/CMSydylgw/201702/201702160515014.pdf. See also PRC Ministry of Foreign Affairs, Carry Forward Silk Road Spirit and Write a New Chapter for Cooperation (June 10, 2017), available at http://www.fmprc.gov.cn/mfa_eng/zxxx_662805/t1469852.shtml.

28 Agreement on Economic and Trade Cooperation between the EAEU and China (May 17, 2018), available at http:// eec.eaeunion.org/ru/act/trade/dotp/sogl_torg/Documents/Forms/Alltems.aspx.

29 PRC Ministry of Environmental Protection, The BR Ecological and Environmental Cooperation Plan, The Belt and Road Portal (May 2017), available at http://www.yidaiyilu.gov.cn/wcm.files/upload/CMSydylgw/201705/201705140543014.pdf; PRC Ministries of Environmental Protection, Foreign Affairs, Commerce and the NDRC, Guidance on Promoting Green BR, Ministry of Ecology and Environment of China (June 28, 2017), available at http://english.mee.gov.cn/Resources/Policies/ policies/Frameworkpl/201706/t20170628 416864.shtml; The NDRC and the State Oceanic Administration of China, Vision for Maritime Cooperation under the BRI, The Belt and Road Portal (June 2017), available at http://www.yidaiyilu.gov.cn/ wcm.files/upload/CMSydylgw/201706/201706200153032.pdf. For details on policy documents and implementation plans issued by relevant governmental ministries and commissions, see The Belt and Road Portal (Policies and Regulations), available at https://eng.yidaiyilu.gov.cn/info/iList.jsp?cat_id=10062.

30 Supra note 1.

31 Id.

32 PRC Ministries of Agriculture, Commerce, Foreign Affairs and the NDRC, Vision and Action on Jointly Promoting Agricultural Cooperation on the Belt and Road [共May 2017), available at http://jiuban.moa.gov.cn/zwllm/zwdt/2O1705/ t20170512_5604724.htm

33 Id.

34 Supra note 1

35 See China Railway Express 列], The Belt and Road Portal (July 20, 2018), available at http://www.yidaiyilu.gov.cn/zchj/ rcjd/60645.htm.

36 See Intergovernmental Agreement of the SCO Member States on the Facilitation of International Road Transport (Sept. 12, 2014), available at http://eng.sectsco.org/load/20768lalong the Asian Highway Network (Dec. 8, 2016), available at https://www.unescap.org/sites/default/files/Intergovernmental-Agreement-on-International-Road-Transport-along-theAsian-Highway-Network-English-language.pdf.

37 Office of the Leading Group for Promoting the BRI, Building the BR: Concept, Practice and China' s Contribution [共建一带一路带理念 实践与中国的贡献], The Belt and Road Portal (May 2017), available at http://www.yidaiyilu.gov.cn/ wcm. files/upload/CMSydylyw/201705/201705110537027.pdf.

38 Supra note 25.

39 Id.

40 Supra note 37.

41 Id.

42 Id.

43 See, e.g., Gwadar port creates economic magic with Chinese help, China Dally, Dec. 12, 2018, available at http:// www.chinadaily.com.cn/a/201811/12/WS5be8d62ba310eff303287f6c.html; Staff reporter, Outlook positive as Hambantota Port grows with opportunities for Sri Lankans, XINHUANET, Dec. 12, 2018, available at http://www.xinhuanet.com/ english/2019-12/24/c_138655160.htm; Staff reporter, Malacca, 'China's gateway to S-E Asia,' Straits Times, Apr. 16, 2017, available at https://www.straitstimes.com/asia/se-asia/malacca-chinas-gateway-to-s-e-asia; Staff reporter, China, Myanmar sign port deal after years of negotiations, GLoBaL Times, Nov. 8, 2018, available at http://www.globaltimes.cn/ content/1126664.shtml.

44 Supra note 8, at 691. 
45 Z. Kembayev, The Emerging Eurasian Union: Problems and Perspectives (July 18, 2014), available at https://static.unigraz.at/fileadmin/rewi-zentren/Reees/Projekte/Zhenis_Kembayev.pdf.

46 For details on "Central Asia plus Japan" Dialogue, see Ministry of Foreign Affairs of Japan, "Central Asia plus Japan" Dialogue, available at https://www.mofa.go.jp/region/europe/dialogue/index.html.

47 B. Jaipragas, Why Is the US Calling Asia-Pacific the Indo-Pacific? Donald Trump to "clarify," South China Morning Post, Nov. 7, 2017, available at http://www.scmp.com/week-asia/politics/article/2118806/why-us-calling-asia-pacific-indopacific-trump-clarify.

48 Staff reporter, India, Vietnam to Sign Deal for Oil Exploration in South China Sea Despite Protest by China, DNA InDIA (Oct. 27, 2014), available at http://www.dnaindia.com/india/report-india-vietnam-to-sign-deal-foroil-exploration-insouth-china-sea-despite-protest-by-china-2029677.

49 Wenhong Xu, Russia, Central Asia Accept BRI Gainful, China Daily, Aug. 23, 2018, available at http:// www.chinadaily.com.cn/a/201808/23/WS5b7df4cba310add14f3873c6.html.

50 Staff reporter, China-Russia Joint Declaration of Further Deepening the Comprehensive Strategic Partnership of CoordinationNeT, July 5, 2017, available at http://www.xinhuanet.com//world/2017-07/05/c_1121263941.htm.

51 PRC Ministry of Commerce, China and Russia Sign the Joint Declaration of the Joint Feasible Studies on Completing Eurasian Economic Partnership Agreement (June 9, 2018), available at http://english.mofcom.gov.cn/article/newsrelease/sig nificantnews/201806/20180602754961.shtml.

52 Ran Guo, Legal Basis of China's Claim over the Huangyan Island, 6 J. EAST Asia \& Int' L L. 531-52 (2013); Sino-Vietnam Dispute over Hydrocarbon Resources Exploration in Nansha Waters after the South China Sea Arbitration, 47 HoNG Kong L. J. 951-85 (2017).

53 Id. at 978

54 See Hillary R. Clinton, Press Statement on Vietnam's National Day (Aug. 31, 2012), available at https://20092017.state.gov/secretary/20092013clinton/rm/2012/08/197209.htm. This position was reaffirmed by the Trump administration at the 6th US-ASEAN Summit and the 33rd East Asia Summit. See P. Murphy, The United States and ASEAN: Forward Together (Nov. 13, 2018), available at https://blogs.state.gov/stories/2018/11/13/en/united-states-andasean-forward-together.

55 Commission on Security and Cooperation in Europe, The New Silk Road Strategy: Implications for Economic Development in Central Asia (July 31, 2013), available at http://www.csce.gov/sites/helsinkicommission.house.gov/files/The\%2ONew\%2O Silk\%2ORoad\%2OStrategy.pdf.

56 B. Naughton, What Will the TPP Mean for China?, Foreign Pol' Y, Oct. 7, 2015, available at http:// www.foreignpolicy.com/2015/10/07/china-tpp-trans-pacific-partnership-obama-us-trade-xi. See also M. Kuo, CPTPP and Leadership in the Global Trade System, Diplomat, Apr. 10, 2018, available at https://thediplomat.com/2018/04/cptppand-leadership-in-the-global-trade-system/.

57 Supra note 1, at V (Cooperation Mechanisms).

58 Id. at II (Principles).

59 On March 17, 2017, the UN Security Council unanimously adopted Resolution 2344, calling on the international community to strengthen regional economic cooperation through the BRI. See also Ufa Declaration of Heads of Member States of SCO (July 10, 2015), available at http://eng.sectsco.org/load/200119/.

60 Supra note 5.

61 Supra note 17.

62 Supra note 1, at V (Cooperation Mechanisms).

63 C. Guluzian, Making Inroads: China's New Silk Road Initiative, 37 CATO J. 145 (2O17).

64 Tao Yang, International Law and the Challenges Faced by the B2-5 (2016).

65 Xiaohui Zhang, Legal Risk Management of Overseas Investment under the BRI [解], 1 InTERnATIONAL ProJeCT ContraCting \& LABOUR SE-6 (2015)

66 Supra note 64

67 Xueping Li, Cooperation Mechanism of the BR: Legal Defects, Challenges and Solutions [ “略] 421 MonTHLY THEORY [理] 5-9 (2017).

68 Supra note 1, Preface.

69 Lingliang Zeng, Conceptual Analysis of China' s BRI: A Road towards a Regional Community of Common Destiny, 15 Chinese J. Int' L. L. 538 (2016).

70 Supra note 1, V (Cooperation Mechanisms).

71 Supra note 63, at 135.

72 Supra note 67.

73 Supra note 69 , at 539

74 Tao Li \& Zuoli Jiang, Implication of the Asian Infrastructure Investment Bank for Global Financial Governance: Accommodation or Confrontation?, 9 Tsinghua China L. Rev. 142 (2016), available at https://papers.ssrn.com/sol3/ 
papers.cfm?abstract_id=2913988.

75 Supra note 5 , at 7 .

76 A thought experiment is a device with which one performs an intentional, structured process of intellectual deliberation in order to speculate, within a specifiable problem domain, about potential consequents (or antecedents) for a designated antecedent (or consequent). See L. Yeates, Thought Experimentation: A Cognitive Approach (July 2004) (Graduate Diploma in Arts dissertation, University of New South Wales) at 150, available at https://archive.org/details/TECA2004/mode/2up.

77 Supra note 5 , at 5 .

78 Supra note 69 , at 527 .

79 Supra note 8 , at 691 .

80 Id. at 168

81 Id. at 183.

82 J. Geddie, Malaysia Renegotiating Terms of Major Belt-and-Road Rail Project: PM Mahathir, Reuters, May 26, 2018, available at https://uk.reuters.com/article/us-malaysia-politics-projects/malaysia-renegotiating-terms-of-major-beltand-road-rail-project-pm-mahathir-idUKKCNIIROFM. See also A. Erickson, Malaysia Cancels Two Big Chinese Projects, Fearing They Will Bankrupt the Country, WASH. POST, Aug. 21, 2018, available at http://www.washingtonpost.com/world/ asia_pacific/malaysia-cancels-two-massive-chinese-projects-fearing-they-will-bankrupt-the-country/2018/08/21/.

83 International lawyers have suggested that China and other BR countries should negotiate and conclude "a comprehensive regional or multilateral BR agreement" or establish "the Silk Road Union." See supra note 69, at 532; supra note 8, at 691-9.

84 Supra note 69 , at 541

85 Supra note 6.

86 B. Hofman, China One Belt One Road Initiative: What We Know Thus Far, ChinaGoAbroad (Apr. 12, 2015), available at http://www.chinagoabroad.com/en/article/china-s-one-belt-one-road-initiative-what-we-know-thus-far.

87 Supra note 5 , at 4 .

88 R. Mushkat, State Reputation and Compliance with International Law: Looking through a Chinese Lens, 10 CHINESE J. ITN' L L. $703-37$ (2011)

89 Yongping Xiao, The International Law for the BR and the Role of China' s Courts [ “ 作用], 15 CHINA TR] 15 (2O15).

90 Supra note 6 , at 13

91 Supra note 5 , at 3.

92 Supra note 7.

93 Supra note 8, at 692.

94 Supra note 67.

95 Xi Jinping, Work Together to Build the Silk Road Economic Belt and the 21st Century Maritime Silk Road-Speech at the Opening Ceremony of the BR Forum for International Cooperation, Xinhuanet, May 14, 2017, available at http:// www.xinhuanet.com/english/2017-05/14/c_136282982.htm.

96 The BR Forum for International Cooperation, List of Deliverables of the BR Forum for International Cooperation, CHINA DAllY, May 16, 2017, available at http://www.chinadaily.com.cn/china/2017-05/16/content_29359377.htm.

97 The 2018 Beijing Summit of the FOCAC adopted the Beijing Declaration-Toward an Even Stronger China-Africa Community with a Shared Future and the FOCAC Beijing Action Plan (2019-2021) on September 4, 2018. See Beijing Declaration, Action Plan Adopted at FOCAC Summit, The Belt and Road Portal (Sept. 5, 2018), available at https://eng.yidaiyilu.gov.cn/qwyw/ rdxw/65061.htm.

98 Supra note 64.

99 The Trade Facilitation Agreement entered into force on February 22, 2017. See Ratifications List, available at http:// www.tfafacility.org/ratifications.

100 Supra note 64

101 Supra note 6, at 11

102 H. Khan \& I. Khalid, New Delhi Response to Beijing "BRI" Project: A Lucid Connection with Chinese "String of Pearls" , 25 J. Pol. Stud. 243-254 (2018).

103 D. Chaudhury, China Wants India in One-Belt-One-belt meet: India remains wary, IndiA Times, Jan. 7, 2017, available at https://economictimes. indiatimes.com/news/politics-and-nation/china-wants-india-in-one-belt-one-road-meet-indiaremains-wary/articleshow/56383009.cms. See also supra note 102, at 247.

104 Supra note 102 , at 248-9.

105 Id.

106 The BRI may become one of the cornerstones of Asian economic growth and integration, and eventually a closer political and security cooperation framework among states. However, the pathway to this scenario is long and fraught with obstacles. See generally R. Ghiasy \& Jiayi Zhou, The Silk Road Economic Belt: Considering Security Implications and EU-China Cooperation Prospects (2017), available at https://www.sipri.org/sites/default/files/The-Silk-Road-Economic- 
Belt.pdf.

107 U.N Charter arts. 1, 24-26 \& 39-51. China should work within the UN and its legal system, instead of creating a new mechanism.

108 Supra note 6, at 17

109 Supra note 37.

110 Supra note 6, at 16.

111 Supra note 69

112 Supra note 95

113 For details on China' s non-alignment policy, see Yusheng Wang, Should China Abandon Non-Alignment?, PEoPle's Dally, Nov. 4, 2012, available at http://en.people.cn/102774/8004263.html.

114 Jingdong Liu, Building Fair and Reasonable Disp6 (2017).

115 Hao-wen Wu, The Mode Selection of the Dispute Settlement Mechanism for the BRI [ " - (2017).

116 China has concluded 16 FTAs with 24 countries and regions. See also Shaohua Sun, More FTAs Due in 2018 [明年ec. 27 , 2017, available at http://dz.jjckb.cn/www/pages/webpage2009/html/2017-12/27/content_39433.htm.

117 Supra note 64.

118 UNCTAD, IIA database, China-Bilateral Investment Treaties, available at http://www.investmentpolicyhub.unctad.org/IIA/ CountryBits/42\#iiaInnerMenu. See also Tingting Deng \& Meiyu Zhang, The Treat6 (2016).

119 Id. See also Jie (Jeanne) Huang, Silk Road Economic Belt: Can Old BITs Fulfil China's New Initiative?, 50 J. WorLd TRADE 733-54 (2016).

120 Supra note 64.

121 Supra note 89, at 15.

122 By February 2018, China had signed 19 treaties on mutual judicial assistance in civil and criminal matters; 41 treaties on criminal judicial assistance; and 18 treaties on judicial assistance in civil and commercial matters. See PRC Ministry of Foreign Affairs, China's Treaties on Judicial Assistance and Extradition (Feb. 2018), available at http://www.fmprc.gov.cn/ web/ziliao_674904/tytj_674911/wgdwdjdsfhzty_674917/t1215630.shtml.

123 Supra note 17.

124 Id.

125 Id.

126 Id.

127 Regulations on Several Issues regarding the Establishment of International Commercial Courts, arts. 2-3.

128 Supra note 82.

129 Supra note 6 , at 12

130 Supra note 63 , at 138

131 D. Arase, China's Two Silk Roads: Implications for Southeast Asia, 2 ISEAS Perspective 405 (2O15).

132 Supra note 69 , at 540 . 